\title{
HET RAPPORT „GOD MET ONS ... OVER DE AARD VAN HET SCHRIFTGEZAG" VAN DE GEREFORMEERDE KERKEN IN NEDERLAND
}

\author{
Prof. Dr. W. H. Velema (Apeldoorn)
}

\section{DOOR DE SYNODE MET ALGEMENE STEMMEN AANVAARD}

Dit rapport werd in Nimes aangekondigd. Op de vergadering van de Gereformeerde Oecumenische Synode, aldaar gehouden in juli 1980, vertelde Dr. H. B. Weijland dat in dit rapport een poging gedaan zou worden om op allerlei problemen die met het verstaan aan de Schrift samenhangen, in te gaan. Hij wekte niet de indruk dat met dit rapport alle problemen zouden worden opgelost. Wel suggereerde hij dat in dit rapport beslissingen zouden vallen, die voor het verstaan van de Schrift en voor het beroep op de Schrift van verstrekkende betekenis zouden zijn. Uiteraard maakte hij het voorbehoud dat de kerk dit rapport zou overnemen en het haar goedkeuring zou geven.

Welnu, dit rapport is met algemene stemmen door de Synode aanvaard. Het wordt op grote schaal verspreid, en naar men mag aannemen, ook bestudeerd en gebruikt. Ik hoorde zelfs al spreken over een oplage van 60.000 exemplaren. De praeses van de Synode sprak op de dag van aanvaarding over een bevrijdend en een verrijkend rapport.

Over de status van dit rapport wordt verschillend geoordeeld. We lezen in het „Ten Geleide": „Uit een en ander zal duidelijk zijn, dat men hier te maken heeft met een studierapport en niet met een nieuw belijden" (4). Prof. Dr. D. Nauta wees er in het Ouderlingenblad echter op dat het rapport meer is dan een studierapport. Het heeft wel degelijk confessionele betekenis ${ }^{1}$. Dat blijkt ook uit de woorden: „De synode biedt dit geschrift nu aan als een handreiking tot een dieper verstaan van de Heilige Schrift" (4). Het gaat in dit geschrift om het belijden van de kerk met betrekking tot de Heilige Schrift. Dat blijkt ook uit het oordeel van de Synode, weergegeven op bladzijde 3: „De Synode herkende het (rapport W.V.) als een duidelijke en confessioneel verantwoorde uiteenzetting over de wijze, waarop de Schrift verstaan wil worden, om te kunnen horen wat de God van het Woord ons te zeggen heeft". Het is niet maar een studierapport, dat eventueel ook nog van de tafel genomen zou kunnen worden. Integendeel, hier worden dingen gezegd met betrekking tot het verstaan van de Schrift, en daarin ook met betrekking tot de Schrift zelf, die kerkleden in deze tijd ter harte moeten gaan, en die zij ook ter harte moeten nemen.

Ongetwijfeld staat de weg open om bezwaar tegen bepaalde passages in te brengen. Het is echter ondenkbaar dat het rapport als zodanig zou worden teruggenomen.

Dit rapport is te typeren als de afsluiting van een bepaalde ontwikkeling en tegelijk ook als het begin van een nieuw tijdperk. Wat hier naar voren wordt gebracht heeft een geschiedenis achter de rug. Het is niet van vandaag of gisteren. Dat blijkt uit het feit 
dat er vanaf de synode $1973 / 75$ aan gewerkt is. Toen begon men met deze studie om ,een zo goed mogelijke onderlinge verstandhouding te bevorderen tussen kerk en theologie, tussen de gemeente enerzijds en het wetenschappelijk onderzoek en onderwijs van de Bijbel, van de kerkgeschiedenis en van de leer van de kerk anderzijds" (3).

De spanning, om niet te zeggen het conflict tussen kerk en theologische wetenschap, zoals dat in de Gereformeerde Kerken sinds de zestiger jaren naar voren is gekomen, ligt op de achtergrond van dit rapport. Het bedoelt een duidelijk en bevredigend antwoord te geven op de problemen die waren gerezen.

$\mathrm{Nu}$ heeft de kerk gesproken. Nog wel eenstemmig. Er waren in de discussie, die aan de beslissing voorafging, wel bezwaren. Zelfs zijn de schrijvers van dit rapport het niet op alle punten met elkaar eens. Niettemin kon de synode zich vinden in dit rapport. De lange weg van heroriëntering in de theologie, waarvoor onderscheiden namen van hoogleraren uit Amsterdam en Kampen kenmerkend zijn, wordt met dit rapport afgesloten. De wissel is omgezet. Er behoeft niet meer gevraagd te worden of de nieuwe ontwikkelingen wel legitiem zijn. Met dit rapport zijn deze ontwikkelingen en principes kerkelijk geijkt.

Een periode van discussie, verontrusting, onzekerheid en strijd wordt met dit rapport afgesloten. Van nu af aan kan de theologie zich op de kerk beroepen. De reikwydte van de beslissing over dit rapport lijkt mij te liggen in het feit dat de kerk- nog wel met algemene stemmen - het standpunt van de moderne ontwikkelingen in de theologie van Kampen en de VU heeft overgenomen en tot het hare heeft gemaakt.

Ik zeg hiermee niet, dat de kerk alle uitlatingen of standpunten van deze theologen voor haar rekening neemt. Wel zeg ik, dat er met dit rapport in de hand geen wezenlijke weerstand meer te bieden is tegen de moderne manier van theologiseren. Ik kan me voorstellen dat bepaalde voorstanders van deze theologie de zaken nog duidelijker, nog scherper, nog progressiever geformuleerd wilden hebben. Anderzijds biedt dit rapport geen enkel middel om fundamentele bezwaren tegen deze theologen in te brengen. De hier verdedigde visie op de Schrift impliceert een hermeneutiek, die hen juist tot hun inzichten heeft gebracht.

Zo wordt er met dit rapport een periode afgesloten. Men kan nu rustig verder gaan op de ingeslagen weg. De synode heeft daarvoor de theologische legitimatie gegeven. Anderzijds breekt nu de tijd aan, zo moeten we vrezen, van de volle ontplooiing van een theologie, die zich wezenlijk van de gereformeerde belijdenis heeft verwijderd.

Het is mij geen vreugde, hier in Potchefstroom, over dit onderwerp te spreken. Liever zou ik een ander onderwerp behandeld hebben. We kunnen echter, ook als leden van de Gereformeerde Oecumenische Synode, niet om dit rapport heen. Het zal in Nederland zeker zijn invloed doen gelden. Daar buiten zal het ook gehoord willen worden. Het is met smart dat ik de dingen aan de orde 
stel. Niet graag praat men over wat er in een zusterkerk fout gaat. Zeker doet men dat niet graag in het buitenland. Mij past bescheidenheid. Niettemin moet ik toch ook duidelijk zeggen wat er in het rapport staat en hoe dat gelezen wil worden.

\section{OVERZICHT VAN DE INHOUD}

Velen uwer hebben nog niet de gelegenheid gehad om het rapport zelf in te zien. Daarom geef ik vrij lange citaten. Ik wil het rapport zelf laten spreken. Ik begin met een overzicht van de inhoud. Op het Ten Geleide van het moderamen van de synode volgt een Inleiding.

Dan komt hoofstuk I „Veranderingen in het waarheidsbegrip". Het is algemeen bekend dat de leidse filosoof prof. Dr. C. A. van Peursen de steller van dit hoofdstuk is. Men herkent trouwens in dit hoofdstuk gedachten uit zijn publicaties ${ }^{2}$.

Het tweede hoofdstuk handelt over „Historisch-kritisch onderzoek van de Bijbel". Hier wordt ingegaan op het ontstaan en de geschiedenis van het historisch-kritisch onderzoek. Het derde hoofdstuk is gewijd aan „De Schriftbeschouwing in de geschiedenis van de Gereformeerde Kerken". Daarin komen Kuyper en Bavinck aan de orde. Ook wordt gesproken over de besluiten van de synoden van Assen 1926 en wat daarop volgde, tot aan het terugnemen van deze besluiten. Hoofdstuk vier beslaat ruim de helft van het rapport $(53-118)$. Het is het materiële hoofdstuk onder de titel „De Aard van het Schriftgezag".

$\mathrm{Na}$ een Inleiding wordt gehandeld over „De fundering van het Schriftgezag; De historische betrouwbaarheid van de Bijbel; De Bijbel als norm voor het leven, en: Hoe vrij is de theologie?

De laatste negen bladzijden zijn gewijd aan de opdracht: „Samen verder."

\section{VERTREKPUNT IN VERANDERINGEN}

Het rapport stelt op meer dan één plaats duidelijk dat het de Bijbel erkent als het Woord van God. „De belijdenis, dat de Bijbel het door de Heilige Geest ingegeven Woord van God is, berust op de Bijbel zelf" (26). Men vindt op de bladzijden 26 en 27 daarvoor tal van Schriftplaatsen aangevoerd. Datzelfde is het geval op bladzijde 58. Op bladzijde 27 wordt aansluiting gezocht bij artikel 3 van de Nederlandse Geloofsbelijdenis en op blz. 60 bij artikel 2 . Ik noem nu de meest omvangrijke en in het oog springende passages. Ook op andere bladzijden komen we de belijdenis tegen dat de Bijbel het Woord van God is.

Ik stel dit met nadruk voorop. Niemand mag zeggen dat die belijdenis in het rapport ontbreekt of wordt afgewezen. Onze moeite met het rapport is gelegen in wat deze belijdenis metterdaad betekent. De ondertitel wijst ook in die richting. Het feit van het Schriftgezag wordt niet ontkend. De aard van het Schriftgezag is in geding.

Laat ik een voorbeeld noemen uit de geschiedenis van kerk en dogma. De Arianen spreken ook over Jezus als de Zoon van 
God. Niettemin werd hun christologie door de kerk afgewezen. Met dit voorbeeld wil ik niet zeggen dat we in dit rapport een Schriftleer hebben die als ariaans is te typeren. Ik gebruik het voorbeeld alleen om duidelijk te maken dat het gebruik van bepaalde termen nog niet gelijk over hun inhoud doet denken ${ }^{3}$. Zo is het ook met de belijdenis dat de Bijbel het Woord van God is. Men kan aan die belijdenis toch een heel verschillende inhoud geven; op zijn minst geheel verschillend van wat in Gereformeerde kring tot heden het geval was. Dat gebeurt inderdaad in dit rapport.

Opvallend is dat het rapport zijn startpunt kiest in de veranderingen die zich in denken en doen voltrekken. Dit feit behoeft niet enkel negatief beoordeeld te worden. Er liggen ook positieve mogelijkheden in. „De bedoeling van de volgende notities is om allereerst op de positieve inzichten te wijzen, die liggen in de hedendaagse veranderingen in het waarheidsbegrip" (9). Verderop lezen we: „De hedendaagse verschuivingen in ons denken en beleven moeten ons dus niet verontrusten, want zij helpen ons juist opnieuw zicht te krijgen op Gods overmacht" (21). Aan het slot wordt hierop nog eens ingegaan: „De ingrijpende overgang naar een ander denkklimaat in onze tijd geeft-naast gevaren! - ook mogelijkheden voor de verkondiging van de bijbelse boodschap" (120).

Het gaat er dus om dat we in de belijdenis omtrent en het bezig zijn met de Heilige Schrift het veranderde denkklimaat van onze tijd velwerken. Het rapport geeft ons zelf de draad in handen om de verandering in visie op de Schrift op te sporen. Die hangt samen met - als men al niet wil zeggen dat ze veroorzaakt zijn door veranderingen in ons denken en doen.

\section{EEN VEEL ACTIEVERE ROL VOOR DE MENS}

Vervolgens is het opvallend dat gewezen wordt op de passieve rol die de mens naar vroegere (gereformeerde) opvatting vervulde bij het tot stand komen van de Schrift. Ik citeer nu wat als een soort samenvatting aan het eind van het rapport wordt gezegd: „Wij hebben getracht uiteen te zetten, dat het gezaghebbende Woord van God op een relationele manier tot ons komt. Het is door bemiddeling van mensen neergelegd in de Schrift en het moet door bemiddeling van mensen weer uit die eeuwenoude schatkamer tevoorschijn gehaald worden. Wij hebben ook gezien, dat in deze formulering een wat minder passieve rol aan de mens wordt toegekend dan wij tot nu toe gewend waren in de gereformeerde traditie" (103). Ook op blz. 62 en 63 wordt gesproken over de passieve rol die in de gereformeerde traditie aan de mens wordt toegekend bij het ontstaan van de Schrift.

Overigens is dit niet de eerste keer dat in het rapport de kwestie van een noodzakelijke overgang van een passieve naar een veel actiever rol van de mens aan de orde komt.

We lezen daarover ook al op blz. 10. Dan gaat het niet speciaal over de Schrift. Daar wordt gehandeld over de waarheid. Het rapport wijst de tot op heden gangbare opvatting van objectieve waarheid af. Deze opvatting is in tal van kringen, ook bij de klassiek gereformeerde theologen te vinden. „Het voordeel van deze 
opvatting is het besef dat om waarheid te spreken men een norm van buitenaf moet erkennen. Waarheid is niet zomaar willekeurig. Het nadeel is dat de mens in deze opvatting wel erg passief is. De waarheid zeggen en kennen vergt toch inspanning, onderzoek, worsteling? Vraagt echte waarheid niet om de activiteit van de mens?" (10).

We zullen ons niet vergissen, als we stellen dat met name het moderne levensklimaat (denken en doen) vraagt om de erkenning van het goed recht van een actieve rol van de mens.

Ik moet erop wijzen dat deze actieve rol van de mens zonder onderscheid bepleit wordt zowel bij het tot stand komen van de waarheid als bij het tot stand komen van de Schrift. Kennelijk gaat het bij deze twee om te vergelijken of parallelle structuren De actieve bijdrage van de mens aan het tot stand komen van de Schrift is te begrijpen en noodzakelijk gezien de actieve bijdrage die de mens aan het tot standkomen van de waarheid heeft - naar hedendaagse opvattingen dan wel te verstaan.

\section{HET WAARHEIDSBEGRIP}

Hoe ziet het waarheidsbegrip in het eerste hoofdstuk er nu uit? Afgewezen wordt de klassieke opvatting, waaronder ook die van de gereformeerde theologie. Deze is te omschrijven als objectieve waarheid. Afgewezen wordt eveneens een totale subjectivering van de waarheid. Er zit aan deze opvatting ,het voordeel dat waarheid niet is een ding of object dat als het ware voor het oprapen ligt, maar iets dat moeizaam aan het licht gebracht moet worden. Waarheid vergt de inzet van de mens - en - een tweede voordeel wordt dan door vele denkers getekend als iets dat de totale inzet van de mens vraagt" (11). Toch ,dreigt de waarheid bij deze opvatting (idealisme en existentialisme, W.H.V.) subjectivistisch te worden. De mens beslist en projecteert, terwijl het richtsnoer van buiten de mens, het "tegenover" ontbreekt" (11).

Het gaat er om een weg te vinden die boven de tegenstelling van objectieve en subjectieve waarheid uitgrijpt. Inleiding daartoe is de opmerking: „Juist een eerlijke en echte houding ten opzichte van de waarheidsvragen is veelal meer overtuigend dan een zeer gesloten, onpersoonlijk overzicht van wat men voor waar moet houden" (12). In deze stelling wordt de positie, die vroeger werd ingenomen, zowel gekarakteriseerd als afgewezen. Het gaat om een nieuw, althans een sterk ,veranderd waarheidsbegrip”, zoals uit de formulering van het opschrift van paragraaf 4 , op blz. 11 blijkt. Het nieuwe waarheidsbegrip is te omschrijven als ,objectief en subjectief inéén" (opschrift van paragraaf 5, blz. 12). Het is meer dan een optelsom van objectief en subjectief samen. „Waarheid is niet zomaar iets buiten de mens, ook niet alleen maar een inspanning van de mens en evenmin een optelsom van beide" (12). Men lette er op hoe hier de posities getekend én afgewezen worden. Objectieve waarheid buiten de mens is karakteristiek voor de positie die vroeger werd ingenomen. De waarheid als worsteling van de mens, als inzet van de mens is de moderne positie. Zij komt uit het existentialisme. 
De remedie voor de kwalen van onze tijd kan de gereformeerde Schriftleer aanbieden in het doen samengaan van beide. Dan moet wel de oude gedachte van een waarheid buiten ons worden losgelaten. Dan moet worden aanvaard de worsteling van de mens, de moeite die hij heeft om de waarheid te vinden. Deze worsteling is niet het een en het al. Ze is echter wel wezenlijk voor het waarheidsbegrip.

„Het is de schat in de akker én het graven én het vinden inéén, anders gezegd: juist in en met het subjectieve aspect komt het objectieve beter aan het licht. Naarmate een mens meer ernst maakt met de waarheid, zich beter inzet en meer zijn eigen en persoonlijk stempel zet op zijn spreken en handelen kan juist het echte en overtuigende van de waarheid voor hemzelf en voor anderen tot uiting komen. En ditzelfde nu vanuit de andere pool: Juist in en met het objectieve aspect komt het subjectieve beter tot zijn recht" (12).

De kernvraag moet in dit verband zijn of de menselijke inzet en moeite alleen het aan de dag brengen van de in zich bestaande waarheid betreft, dan wel of deze menselijke inzet zelf ook deel van de waarheid is; althans deel uitmaakt van het tot stand brengen, in de zin van constitueren van de waarheid.

De reeds geciteerde uitdrukking ,tot uiting komen" treffen we ook aan op blz. 16. Deze uitdrukking wijst in de richting van het aan het licht brengen van de waarheid door menselijke inspanning. Men vraagt zich dan wel af, of de waarheid niet zelf zoveel licht is, dat zij uit zichzelf het donker verdrijft.

Juist wie Jezus Christus als de Waarheid belijdt en Hom ook kent als het Licht der wereld (Joh. 8:12) moet wel moeite hebben met de gedachte dat onze worsteling Hem als Waarheid tot uiting brengt. Wij zouden dan door onze moeite licht moeten brengen, terwijl Hij Zelf hêt Licht is.

Daarom maakt juist de uitdrukking „tot uiting komen" ons behoedzaam. We kunnen niet zomaar concluderen dat de zozeer noodzakelijke geachte actieve rol van de mens enkel het aan de oppervlakte brengen van de waarheid betreft. Wie het noodzakelijk acht dat de mens de waarheid met moeite aan het licht brengt, heeft daarmee ipso facto een waarheidsbegrip, dat op zijn minst de mens nodig heeft om het licht te laten schijnen.

Het reeds geciteerde beeld van de schat in de akker én het graven én vinden inéén als omschrijving van waarheid, doet ons zeggen: Bij wat het rapport onder waarheid verstaat hoort wezenlijk de activiteit van de mens. Die activiteit betreft niet alleen het aan het licht brengen van de waarheidsschat. Neen, het zoeken en vinden is onderdeel van het hele proces, dat als waarheid wordt omschreven.

Deze interpretatie wordt ondersteund door het feit dat het rapport zelf de waarheid een relatie noemt tussen subject en object, zelfs een wisselwerking. „Waarheid is dus niet alleen buiten het menselijk subject te vinden, maar ook niet louter binnen die mens. Waarheid is meer, het gaat steeds om de betrokkenheid van de mens bij iets anders en om de overtuigingskracht van iets anders (een verkeersteken, een zedelijke overtuiging, een visie, een leer- 
stuk) die pas in de mens tot stand komt en zichtbaar wordt. Met andere woorden: $\mathrm{Er}$ is sprake van een relatie tussen subject en object, sterker nog: een wisselwerking waardoor beide zich eigenlijk pas goed gaan aftekenen" (14).

Deze formuleringen lijken mij alleen uitgelegd te kunnen worden in deze zin, dat onze menselijke inspanning en bijdrage (samen te vatten als de grotere activiteit, vergeleken met de vroegere passieve rol van de mens) constituerend is voor de waarheid. Ik preciseer mede constituerend. In elk geval is er geen waarheid zonder déze menselijke inzet.

Dat wordt overduidelijk door wat we lezen op blz. 12/13: „Naarmate iets ons dieper raakt, ons meer aangrijpt, naarmate we meer overweldigd worden door een waarheid die als het ware op ons afkomt, in die mate zal juist onze eigen manier van de dingen zeggen, onze persoonlijke inzet, deel blijken uit te maken van deze op ons toekomende waarheid".

De waarheid valt dus niet samen met onze persoonlijke visie. $\mathrm{Er}$ is iets meer dan wat wij uit onszelf opdelven en voor waarheid uitgeven. Wij moeten betrokken zijn op iets buiten ons.

Doch die waarheid is voor ons, tot in zijn formuleringen toe, geen waarheid zonder onze actieve betrokkenheid daarbij. Ik moet dus concluderen dat onze formulering, die weer aan het verstaan van ons zelf ontspringt, deel uitmaakt van de waarheid. Hierin ligt kennelijk het nieuwe, dat het rapport noodzakelijk acht. De verwerking van het moderne denkklimaat uit zich in dit bipolaire waarheidsbegrip. Ik acht $\mathrm{mij}$ tot deze conclusie des te meer gerechtigd omdat direct op het gegeven citaat volgt: „Het gaat dus niet om een waarheid (objectief) die vervolgens toegeëigend moet worden (subjectief) maar om beide inéén" (13).

De Gereformeerde pneumat-logie kent sterk de gedachte van de applicatie ${ }^{4}$. Die gedachtelijn wordt hier afgewezen. Ik acht dat een breuk met een belangrijk stuk gereformeerd denken. Het gaat niet maar om de toeëigening van de waarheid, als de mens actiever voorgesteld wordt dan men hem vroeger dacht. Het gaat om het mede-constitueren van de waarheid. De reeds besproken term „tot uiting brengen" kan dan ook niet vanuit het applicatie schema worden gevuld. Ze moet worden verstaan binnen het bi-polaire denken dat de eigenlijke basis vormt voor het hier verdedigde waarheidsbegrip ".

Het komt er ook op neer dat de waarheid eigenlijk nooit af is. Elke formulering is een poging. Geen enkele formulering is het verwoorden van dé waarheid. Het relationele van dit waarheidsbegrip is tegelijk ook het relativerende. „Zo moeten ook theologische formules, die onmisbaar zijn verder wijzen naar een vollere werkelijkheid, die vanuit deze bijzondere, alles omspannende waarheid pas het rijkste geheim van deze wereld in het zicht doet komen. Nieuwe en positieve wegen voor verkondiging liggen voor ons" (23).

Het betekent toch niet het rapport onrecht aandoen, als we zeggen: de nieuwe en positieve wegen bestaan mede, zo niet vooral, in datgene wat wij mensen van onze tijd in het ontdekken en ver- 
woorden van de waarheid tot stand weten te brengen. Zo zijn we de eeuwen door op weg naar de volle waarheid.

HET RELATIONELE KARAKTER VAN DE BIJBEL

In het rapport wordt zonder nadere verantwoording of explicatie het relationele karakter van de waarheid overgebracht op het feit dat de Schrift in een relatie tot stand is gekomen. Twee citaten ten bewijze hiervan: „De Bijbel is het resultaat van een bijzondere relatie tussen God en uitverkoren mensen" (60). Deze zin is de conclusie uit een uitvoerige weergave van teksten waarin de Bijbelschrijvers geinspireerd heten. „Inspirerend' 'in het hedendaagse spraakgebruik betekent ,dat wij door het handelen of spreken van iemand" aan het denken en handelen gezet worden. „Het beginsel, het meeslepende idee komt wel van die ander, maar wij voelen ons gedrongen er zelf mee aan de gang te gaan en het toe te passen in onze eigen situatie. Op soortgelijke wijze moeten wij ons het proces van de Schriftinspiratie indenken" (57). De moderne opvatting van inspirerend biedt dus de mogelijkheid om het bijbelse begrip van inspiratie te verstaan. Ik denk dat we de volgorde ons eerder omgekeerd zouden moeten denken.

Het is geen wonder dat in hoofdstuk III (De Schriftbeschouwing in de geschiedenis van de Gereformeerde Kerken) gewezen wordt op een verschuiving. Aanvankelijk was alle aandacht geconcentreerd op het ontstaan van de Schrift. $\mathrm{Nu}$ is de aandacht gericht op het verstaan van de Schrift. „De vraag naar de juiste uitleg werd niet meer zozeer vanuit de oorsprong der Schrift in het verleden, als wel vanuit de werking der Schrift in het heden aangevat. Daaragter ligt deze visie: de uitleg van de Bijbel is nooit los te maken van de toepassing van de bijbelse boodschap in eigen leven en wereld. Alleen diegene verstaat een tekst echt, die verneemt, hoe deze in eigen situatie spreek" (49). Van 't Spijker spreekt in dit verband over het uitwassen van het onderscheid tussen imperatie en illuminatie (6e artikel, 1 mei 1981). In elk geval is duidelijk dat deze opvatting over inspiratie geheel past in het kader van de als bipolariteit gedachte verhouding van God en mens. „God blijkt Zijn werk op aarde gewoonlijk in bondgenootschap met uitverkoren mensen te verrichten" (62). Deze gedachte zou tot een wat andere formulering van artikel 3 van de Geloofsbelijdenis kunnen brengen. „Maar strikt nodig is dat niet. De tekst van het artikel biedt zelf voldoende ruimte voor de hier bepleite opvatting. In artikel 3 wordt immers onderscheid gemaakt tussen het werk van de Heilige Geest bij de verkondiging van het Woord Gods en de teboekstelling van de Heilige Schrifturen" (62).

In het licht van deze citaten moeten we zelfs zeggen dat de titel "God met ons" geheel beantwoordt aan het schema van de relationele waarheid. Deze titel wijst niet slechts op de inhoud van de Schrift. Hij wijst er ook op hoe die inhoud tot stand komt. 
geciteerde passages waren uit het vierde hoofdstuk. Er blijkt een zeer nauwe verwantschap te bestaan tussen het relationele spreken over de waarheid én over het tot stand komen van de Schrift.

Hoe fundamenteel het relationele van de waarheid is blijkt ook uit de vage formuleringen die gebruikt worden om God, de Ander in deze bi-polaire verhouding te omschrijven.

Er worden dingen beleefd door te mens. Er zijn echt menselijke gebeurtenissen en geschiedenissen. Mensen ervaren in die geschiedenissen de derde dimensie. Dat is de goddelijke Aanwezigheid. De inspiratie door de Geest bestaat eigenlijk hierin dat mensen erkennen: hier gebeurt iets dat niet uit ons opkomt. „De werking van de Heilige Geest doet menselijke geschiedenissen en woorden en op-schrift-stelling tegelijkertijd boven zichzelf uitwijzen" (15).

Het gaat om gebeurtenissen ,waarin de mens een bovenmenselijke Macht tegemoetkwam" (17).

De waarheid wordt onder woorden gebracht als de mens deze vreemde overmacht in de dagelijkse gebeurtenissen herkent en belijdt. „Want de Heilige Geest, die goddelijke kracht, werkt als een gebeuren, als het waaien van de wind. De Heilige Geest is de manifestatie van een vreemde overmacht, samen met de menselijke herkenning en benoeming ervan" (15).

Hier is niet alleen de waarheid een bi-polair gebeuren, doch zelfs de Heilige Geest. Zijn werk wordt gekenmerkt door het relationele karakter van de verhouding van God en mens. God zal zeker de eerste zijn in deze verhouding. Doch God kan niet de eerste zijn zonder dat wij erbij zijn, en zonder dat wij een bijdrage leveren.

„Als het goed is wordt een spreken dat „van boven” komt niet verwaterd, maar komt juist volledig tot z'n recht door het „van beneden". Anders gezegd: de Openbaring zet de eigensoortige, cultureel-historisch bepaalde manieren van leven en denken van de mens niet buiten spel, maar schakelt deze juist in" (17) ${ }^{\circ}$.

Gods waarheid is er niet zonder dat de mens haar formuleert. Dat met de middelen en gedachtenwereld van zijn tijd formuleren van de waarheid is wezenlijk voor de waarheid. Geen wonder dat de mens in later tijden tot andere formuleringen komt. Hij moet dat wel, want hij is een historisch wezen.

God is er, maar hij laat zich niet kennen zonder de mens, die Hem als dimensie van zijn bestaan herkent. „De Bijbel spreekt inderdaad van een goddelijke Stem, als werkelijkheid. Het christelijk geloof is daar een antwoord op. Het antwoord op een Macht die zich zo overtuigend manifesteert dat het daar niet onderuit kan.

"Openbaring" wil dan zeggen dat voor de christenen de dingen om hen heen (schepping de gebeurtenissen van mens en wereld (geschiedenis), de verhalen en spreuken die uit een oude traditie tot hen komen (Bijbel) enerzijds gewome dingen en woorden zijn, anderzijds hun wezenlijke betekenis missen als niet de derde dimensie,, de beslissende betekenis van goddelijke Aanwezigheid erin onderkent word" (20). 
Men lette erop hoe probleemloos in dit citaat van de goddelike stem overgesprongen wordt naar Openbaring als herkenning van die Stem in de gewone gebeurtenissen. Het is geen wonder dat voor de omschrijving van God hier zeer algemene termen (Stem, Aanwezigheid, Overmacht) worden gebruikt. Immers de aankleding, of wil men inkleding is mede onze zaak. God geeft zich immers door onze benoeming te kennen. Openbaring is niet: Zo zegt de Here. Openbaring is het gebeuren waarin wij vorm, verwoording geven aan de stem die wij gehoord hebben. Onze verwoording is even wezenlijk als het gehoord hebben van de Stem. Die Stem is voor anderen zelfs niet meer te kennen, dan door onze stem heen. Hoe ingrijpend dit schema is, moge blijken uit het feit dat op blz. 19 gezegd wordt: „Eeuwigheid is dan geen tijdloosheid die buiten de tijd geheel op zichzelf staat, maar veeleer de volkomen relatie van de tijdelijke mens tot zijn God". Hier wordt de volgorde in de verhouding God-mens zelfs omgekeerd. Niet God als de Eeuwige stelt zich in relatie tot de mens en kwalificeert als zodanig de relatie. De volkomen relatie van de mens tot God, heet hier eeuwigheid.

Het is mij niet mogelijk hier dieper in te gaan op die wijsgerige, met name antropologische herkomst van deze gedachtengang. Men moet dan namen noemen als die van Arnold Gehlen en Wolfhart Pannenberg?. Gehlen schetst de mens als een Mangelwesen. Hem ontbreekt iets. Hij grijpt boven zichzelf uit. Welnu, die leegte wordt hier gevuld met de stem van God.

Ik zie niet voorbij aan het feit dat Gods Aanwezigheid volgens het rapport wezenlijk is voor de mens. Ik stel tegelijk dat de inhoudelijke bepaling van vage termen als Overmacht, Aanwezigheid en Stem van de mens komt. God en mens zijn onskeidbaar, relationeel verbonden.

Het is geen wonder dat de bekende onderscheiding tussen algemene en bijzondere openbaring vervalt. $\mathrm{Zij}$ is in dit schema overbodig. Immers in alles spreekt de Stem. Er is wellicht verschil in volume. In elk geval is Gods Aanwezigheid in Jezus Christus het meest omvattende. Het gebruik van de superlativus doet mij zeggen: hier is geen kwalitatief verschil vergeleken met Gods Aanwezigheid in gebeurtenissen. De afwezigheid van een kwalitatief verschil blijkt ook daaruit dat Gods Aanwezigheid in Jezus Christus de meest algemene openbaring heet. De bijzondere openbaring is hier dus tegelijk de meest algemene. Hoe men ook over het gebruik van deze termen oordeelt, zij hebben een radikaal andere inhoud dan ze tot heden in de gereformeerde theologie hadden. Die andere inhoud is te danken aan het andere schema: aan de verwerking van het moderne levensgevoel, dat ons noodzaakt actiever over de rol van mens te spreken bij het tot standkomen zowel van de waarheid als van de Schrift.

\section{DE SCHRIFT IN KEIN EN WEZEN HISTORISCH}

Dit alles heeft ook directe gevolgen voor de visie op de Schrift. Als de mens zo zijn bijdrage levert, vertoont het product ook sporen van de menselijke bijdrage. Dat komen we tegen in de nu te releveren gedachtengang. $\mathrm{Zij}$ wordt gevonden in het vierde hoofdstuk 
van het rapport. Ze is evenwel de materiële, praktische verwerking van hetgeen in het eerste hoofdstuk over het relationele waarheidsbegrip werd gezegd. Het vierde hoofdstuk neemt het daar gestelde op voor wat betreft het spreken over het ontstaan van de Schrift. Er is geen sprake van dat men het eerste hoofdstuk als een zwerfsteen of „Fremdkörper"wel buiten beschouwing kan laten. Het biedt voor het vierde hoofdstuk het eigenlijke instrumentarium om te spreken over ontstaan en inhoud van de Schrift. Dit instrumentarium is op zijn beurt beslissend voor de hermeneutiek, die bij het lezen en prediken van de Schrift gehanteerd moet worden.

Voor de visie op de Schrift betekent deze benadering: „Alles bijeengenomen: wetenschappelijk gesien is er onvoldoende grond voor de bewering, dat de Bijbel in historisch opzicht betrouwbaarder zou zijn dan andere bronnen" (67). Deze conclusie wordt getrokken uit beschouwingen over volksverhalen. We treffen die aan bij de berichten over de dood van Goliath. Het is uit de Schrift niet af te leiden of David dan wel Elhanan Goliath heeft gedood. Een bijzondere vorm van volksverhaal treffen we daar aan, waar het om de etiologie gaat. Verhalen geven antwoord op de vraag waarom een bepaalde plaats heilig is, of waarom een bepaalde persoon zo heet. Als voorbeeld wordt dan het verhaal van Lot en zijn dochters aangehaald. Moab heeft daaraan zijn naam te danken. De moraal van het verhaal is: Moabieten en Ammonieten zijn bastaards. Volkse humor speelt hier een rol. We zouden deze vertelling beslist te serieus nemen als we er geschiedschrijving in zagen (66). Zelfs de gedachte dat in Israël de bijbelse geschiedschrijving een uniek karakter zou dragen is niet houdbaar. Het is niet waar dat Israël een lineaire geschiedbeschrijving zou hebben in tegenstelling tot het cyclische denken van de omwonende volken. Er is wel verschil. Dat is gelegen in het Godsbegrip. „Wat de bijbelse geschiedschrijving betreft ligt dit eigene vooral in een geheel eigen Godsbegrip" (69).

We vragen ons af hoe deze uitdrukking zich rijmen laat met de overtuiging dat we in Oud en Nieuw Testament te doen hebben met openbaring van Godswege. Als het rapport de Schrift het Woord van God noemt, dienen we op het bemiddeld karakter van dat Woord wel alle nadruk te leggen. Dat blijkt ook uit het vervolg. Voor de Bijbel geldt hetzelfde als voor ons: „hij is in zijn kern en wezen historisch" (69). Dan wordt voor de Bijbel hetzelfde gepostuleerd als voor alle andere documenten uit het verleden: ,, $\mathrm{Zij}$ is geschiedenis naar de omschrijving die de bekende historicus Huizinga daarvan gaf: „de vorm waarin een vultuur zich rekenschap geeft van haar verleden" (70). Het valt ons wel bijzonder moeilijk om bij zulke boute uitspraken nog de gedachte vast te houden dat we in de bijbelse geschiedbeschryving te doen hebben met openbaring van Godswege. Israël geeft zich in deze vorm rekenschap van zijn verleden.

Vandaar ook dat we niet meer moeten denken aan het letterlijk gebeurd zijn van het beschrevene. „Dat is een verouderd begrip van betrouwbaarheid, dat stamt uit de periode vó́r de historische kritiek. Tegen de achtergrond van de inzichten van de historisch- 
kritische wetenschap raakt dit begrip onvermijdelijk uit de tijd, omdat het de afstand tussen wat gebeurd is en wat verteld wordt, voorbijgaat" (70) .

Het rapport verdedigt heel sterk dat de bijbelse waarheid geloofswaarheid is. In die zin is de Bijbel betrouwbaar (73-75). Hoe vanzelfsprekend de Bijbelschrijvers ook in het weergeven van feiten als geloofsgetuigen worden beschouwd blijkt uit de volgende passage: „Maar daar staat dan wel tegenover de intense betrokkenheid van de evangelisten bij wat zij van Jezus gezien en gehoord hadden. De wereld was voor hen na die ontmoeting met hun Heiland eenvoudig niet dezelfde meer. Daarom konden zij alleen door de bril van het geloof terugblikken op het leven van Jesus" (75).

Op deze woorden volgt een paragraaf die tot titel heeft „De geloofsinterpretatie van de geschiedenis" (75). We citeren de in kader afgedrukte samenvatting. Hierin treft men de strekking van de term geloofsinterpretatie van de geschiedenis wel zeer geconcretiseerd aan: „Dit leidt niet alleen tot een nieuwe uitleg van het Oude Testament, het kleurt ook de wijze waarop de evangelisten het leven van Jesus vele jaren na zijn dood schetsen. Zij hebben niet louter verslag willen doen van zijn historische optreden, maar hebben tevens aangegeven, welke betekenis theologisch gezien aan Zijn woorden en daden toegekend moest worden. De evangeliën berusten dus tegelijk op de geschiedenis van Jesus van Nazareth èn op het gelovig verstaan daarvan door de eerste christelijke gemeente" (75).

Er is sprake van een herinterpretatie van het Oude Testament. Deze is „,deels geworteld in de prediking van Jesus zelf" (77). „Maar een ander deel is ongetwijfeld toe te schrijven aan de intensieve bestudering van het Oude Testament binnen de vroeg-christelijke gemeenten" (77). „Waar het nu om gaat is dit: de evangelisten hebben dit nieuwe inzicht in het Oude Testament als het ware teruggeprojecteerd in hun nieuw-testamentisch relaas omtrent de woorden en daden van Jezus. Vaak zal de prediking en het handelen van Jezus Zelf daarvoor aanknopingspunten gegeven hebben. Maar in veel gevallen zal Jezus het niet precies zo gezegd hebben of gedaan hebben als de evangelist het beschrijft. De evangelist maakt dan in overeenstemming met de in het oude Oosten geaccepteerde praktijk, gebruik van een historische vormgewing om de blijde boodschap van Jezus Christus vanuit het Oude Testament te prediken. Hij doet dit op grond van de overtuiging dat de geschiedenis van Gods verlossend werk, waarover in het Oude Testament gesproken wordt, in Christus haar hoogtepunt en vervulling vindt" (77).

„Want het is volstrekt duidelijk dat die evangelisten niet alleen de leer van Jezus (of hun eigen theologische verwerking daarvan) hebben willen doorgeven. (Dat dus ook, W.H.V.) $\mathrm{Zij}$ poogden ók de diepe indruk vast te houden, die het historische optreden van Jezus op hen gemaakt had. De evangeliën berusten niet of op de geschiedenis van Jezus van Nazareth of op het geloof van de eerste christenen - zij berusten op beide tegelijk" (78).

Men beseffe welke vérstrekkende konsekwenties het gebruik van termen als "de overtuiging van de evangelisten", of "het willen 
vasthouden van de diepe indruk die Jezus op hen heeft gemaakt" meebrengt. Hoe is het mogelijk in een beschouwing die zulke termen gebruikt nog van door de Geest geautoriseerde overlevering van Jezus' woorden en daden te spreken. Daarom gaat het toch, als het Nieuwe Testament het woord marturia gebruik. Het is dan ook geen wonder dat prof. Herman Ridderbos juist op dit punt uitermate kritische vragen aan de opstellers van het rapport heeft gesteld".

$\mathrm{Na}$ deze uiteenzetting volgt een paragraaf die tot titel draagt: „De relationele benadering van de werkelijkheid". De in kader afgedrukte samenvatting luidt: „Men kan zeggen, dat de bijbelse visie op de waarheid goed aansluit bij wat eerder in deze nota omschreven is als het relationele waarheidsbegrip. Het gelovige subject (de bijbelschrijver) kan zichzelf niet op een of andere wijze buiten spel zetten om zodoende de „objectieve" waarheid aan het licht te brengen" (78).

Twee punten dienen onderstreept te worden. De bijbelse visie op de waarheid sluit goed aan bij wat reeds eerder over het relationele waarheidsbegrip werd gezegd. Dat waarheidsbegrip is van wijsgerige aard en herkomst. De Bijbel gaat niet voorop. De Bijbel, met name opgevat als geloofsgetuigenis, klopt met dit algemeen menselijk waarheidsbegrip. De vraag mag echter gesteld worden hoe algemeen aanvaard dit waarheidsbegrip is.

Vervolgens wordt heel duidelijk gesteld: De bijbelschrijvers hebben het Woord Gods niet anders kunnen schrijven dan als geloofsgetuigenis. Dat de Bijbel het Woord van God is, kan derhalve alleen worden gezegd met aanvaarding van het relationele waarheidsbegrip en van de Bijbel als geloofsgetuigenis. In het begin schreef $\mathrm{ik}$ over de moeite met wat het rapport eigenlijk verstaat onder die uitspraak dat de Bijbel is het Woord van God. Nu wordt deze veel duidelijker. Er is een kader waarbinnen deze uitspraak past. Dat kader moet tegelijkentijd aanvaard worden. Wie het kader verwerpt, kan de uitspraak niet overeind houden.

\section{CONSEQUENTIES VOOR TOT STANDKOMING VAN DE SCHRIFT}

Hoe ingrijpend de consequenties van de relationele benadering van de werkelijkheid zijn voor de visie op het tot stand komen van de Schrift blijkt uit hetgeen in deze paragraaf metterdaad gesteld wordt.

„De relationele kijk op de werkelijkheid houdt de erkenning in dat die bijbelschrijver (het subject) zichzelf niet op een of andere wijze buiten spel kon zetten. Ook in het Nieuwe Testament zijn daarvan vele sporen te vinden. Het gaat de evangelist natuurlijk om de geschiedenis van Jezus, maar toch altijd in directe relatie tot henzelf. Bepaalde woorden en daden van Jezus kregen door de loop der geschiedenis en onder invloed van de theologische ontwikkelingen binnen de eerste christelijke gemeenten waarvan de evangelisten deel uitmaakten, achteraf als het ware een extra gewicht, dat ook tot uitdrukking gebracht moest worden. Dan pas zou immers een waarheidsgetrouw beeld ontstaan" (81). Dan wordt als voorbeeld genoemd de rede van Jezus over de laaste dingen, in Mattheüs 24 en 25, Marcus 13 en Lucas 21. „Deze rede zal wel aanknopen bij 
bepaalde historische uitspraken van Jesus, bijvoorbeeld Zijn voorzegging over de verwoesting van de tempel". Uitgangspunt is echter de situatie van de latere gemeente (82).

Samenvattend: „De historische werkelijkheid van Gods openbaring in Christus was slechts te beschrijven door degenen die deze werkelijkheid in het geloof hebben aanvaard. De bijbelse geschiedschrijving is dus tegelijk - en onlosmakelijk daarmee verbonden een geloofsgetuigenis" (83).

\section{RELATIE TOT HET WONDER}

Deze relationele benadering geldt ook de aanvaarding van het wonder. De passage die we nu gaan citeren handelt niet meer over de bijbelschrijver, die het wonder als te zijn geschied aanvaardt, en het zo beschrijft. Neen, het gaat over de mens die deze geschiedenis van het wonder leest. Opnieuw een voorbeeld ervan hoe de relationele benadering overgebracht wordt van de mens die schrijft, naar de mens die het geschrevene leest en verwerkt.

De erkenning dat iets een wonder is, vereist dus altijd geloof, zelfs als het gebeuren zintuigelijk waargenomen wordt. De waarheid van het wonder is daarom sterk relationeel bepaald. „Alleen als er een zeer innige band bestaat met het gebeuren of met degene aan wie het wonder wordt toegeschreven, zal het wonder als waarheid worden aanvaard. Wie een relationeel waarheidsbegrip aanhangt, zal de mogelijkheid van het wonder pricipieel open moeten houden. Niet alleen voor toen, maar ook voor nu" (86).

Hier wordt de mogelijkheid van het wonder gefundeerd in het relationele waarheidsbegrip. Niet in God die wonderen doet. Bovendien wordt het aanvaarden van het wonder als waarheid afhankelijk gesteld van de innigheid van de band met het gebeuren of met hem aan wie het wordt toegeschreven. Gaat het hier alleen om de gedachte dat slechts de gelovige zich door de boodschap van de Bijbel laat gezeggen? Of gaat het er ook om dat naarmate de band inniger is, iemand meer gebeurtenissen als wonder zal aanvaarden? Ik kan mij niet aan de gedachte onttrekken dat dit laaste inderdaad wordt gesteld. De innige relatie doet het beschrevene als wonder aanvaarden. Het gaat niet slechts om de interpretatie van wat geschied is (wel met het gelovig verstaan ervan). Het gaat evenzeer om het al of niet geschied zijn. Dat wordt bepaald door de mate waarin men gelooft. Zelfs wie het verhaalde wonder leest, moet voor het antwoord op de vraag of hij het als een geschied wonder aanvaardt, verwezen naar de innigheid van zijn band met het verhaalde en met hem aan wie het verhaalde wordt toegeschreven. Ik kan hieruit alleen maar concluderen dat het wonder gesubjectiveerd wordt.

Ik meen dat te sterker te moeten zeggen, omdat op blz. 87 over een verschil in soortgelijk gewicht van wonderen wordt gesproken. Niet elk wonder staat even dicht bij wat wij als het centrum van de openbaring zien. Hier wordt dus van de bijbellezer zelf gevraagd te onderscheiden tussen centraal en meer perifeer gelegen wonderen. Wat daarvoor de maatstaf is, wordt er niet bij gezegd. In het licht 
van het voorgaande mag men zeker de reeds genoemde innigheid van de band als maatstaf beschouwen.

Op blz. 88 wordt ditzelfde criterium nog eens genoemd. Daar dient het als criterium voor de beantwoording van de vraag of wonderen mogelijk zijn. Of men een beschreven gebeurtenis als wonder aanvaardt, zal mede van de innigheid van de relatie tussen Christus en de mens afhankelijk zijn. Het centrale wonder, de opstanding van Christus, wordt voorgesteld als een zaak waar wij als christenen allen bij betrokken zijn. We zullen daarover des te minder verschil van mening hebben. Wel wordt op blz. 89 gezegd dat de opstanding voor ons geen gewone geschiedenis mag worden. Het moet een wonder blijven waarmee iets te vergelijken is. Ik begrijp de uitdrukking ,geen gewone geschiedenis" niet. Als er één gebeurtenis is die in het Nieuwe Testament voor ons geen gewone geschiedenis kan zijn, dan wel de opstanding.

Bedoelen de schrijvers dat de opstanding geschiedenis van een andere soort is? Dat is toch niet aanvaardbaar. Wij moeten Jezus wonderen waar maken, lezen we op blz. 88. Dat zal in deze wereld hier en nu moeten geschieden. Dan zal het grote wonder van de opstanding toch ook hier en nu geschied moeten zijn. Inderdaad, hoe wonderbaarlijk het ook is, hoe voor ons mensen onverklaarbaar het ook is, in déze ónze wereld is Jezus, de aan het kruis gestorvene, tot het leven terug gekomen. Hij heeft het leven in deze onze werkelijkheid ten toon gespreid. Hij was geen spookverschijning. $\mathrm{Hij}$ toonde de littekens van de wonden in Zijn handen en vroeg om voedsel. Zo werkelijk was Zijn aanwezigheid voor de discipelen, daar en toen.

We gaan nu niet diep in op de merkwaardige manier waarop de geschiedenis van Thomas uitgelegd en toegepast wordt. Het kwam voor hem inderdaad op het geloven aan. Doch dat betrof geen geloven van wat niet gezien kon worden. Juist het geloven van wat te zien was, vroeg Jezus van Thomas.

\section{HET LIEFDEGEBOD HET HOOGSTE GEBOD}

Op één punt moet ik nog wijzen. Dat is de manier waarop het liefdegebod als het grote gebod wordt aangewezen en aangeprezen. Op blz. 93 wordt gesproken over het bijbelse gebod dat voor ons een zekere overeenkomst zal opleveren: "Hoe kunnen wij, in onze eigen situatie op overeenkomstige wijze leven vanuit het heil dat in die tekst ontvouwd wordt?" Op blz. 103 wordt met zoveel woorden over een model, een voorbeeld gesproken dat ons in de geboden wordt geboden. Het is bijna onmogelijk hier niet de gedachten van Kuitert te horen meeklinken ${ }^{10}$.

Met betrekking tot het verbod tot echtscheiding wordt gezegd: „De onhoudbare praktijk heeft geleid tot een herlezen van de Schrift en tot een nieuw verstaan van de bijbelse vorm, namelijk niet als een absoluut verbod, maar als een verbod waarvan slechts een gewogen toepassing mogelijk is. De bijbelse fundering van het huwelijk in de liefde woog zwaarder dan het specifieke gebod" (95). De bijbelse normen moeten altijd tegen de achtergrond van hun historische situatie bekeken worden. Dan behoort de eerste vraag te 
zijn: „Welke heilzame uitwerking beoogde God met dit gebod in die specifieke situatie?" (96).

We zijn met deze redenering toch wel een heel eind op de weg van de situatie-ethiek. Met dien verstande dat het liefdegebod boven alles gaat, en dat in de situatie uitgemaakt moet worden, welke beslissing er genomen moet worden. Hier komt op zijn minst de liefde te staan tegenover de letter van de wet; en niet alleen tegenover de letter, maar evenzeer tegenover de inhoud. Die inhoud is van mindere betekenis dan de eis der liefde. De gewogen toepassing geeft het recht het (letterlijke) gebod te laten varen ten gunste van de eis der liefde.

Ik meen niet aan inlegkunde te doen als ik het zo stel. Ik ben juist met uitlegkunde van deze gedachtengang bezig. We lezen: „Het kan niet de bedoeling zijn dat de vervulling van de kleinere, meer op het bijzondere gerichte geboden ooit in strijd komt met de vervulling van het grote liefdegebod. De vervulling van iedere wet moet uitlopen op leven en vrede, naar de gezindheid van de Heilige Geest die in ons werkt" (94).

Ik zeg niet dat men de letter van het gebod als niets acht. Wel wordt zij als het kleinere gebod ondergeschikt gemaakt aan het liefdesgebod. Deze onderschikking brengt tegelijk haar relativering mee. Het is opvallend dat het rapport met betrekking tot strijdwagens die religieus ontoelaatbaar heten, stelt: Wij mogen "niet lichtvaardig concluderen dat het Oude Testament op dit punt voor ons niet maatgewend zou zijn" (100). Een dergelijke uitdrukking lijkt mij moeilijk verenigbaar met de reeds gebruikte termen als voorbeeld en gebod.

\section{HOE DE BIJBEL OVER WAARHEID SPREEKT}

Wij achten dit relationele waarheidsbegrip in strijd met de stelligheid die juist vanuit de geopenbaarde en ontvangen waarheid in het Nieuwe Testament te horen is. Men bedenke bij de volgende teksten eens dat zij zouden gelden onder beding van het feit dat de waarheid in relatie tot stand gekomen is, of selfs gebracht moet worden.

Paulus roept er toe zich aan de waarheid te houden. Zo alleen is het mogelijk de dwaalleer te bestrijden, Efeze 4:15. Jacobus spreekt er over het de gelovigen zijn voortgebracht door het woord der waarheid (Jac. 1:18). In de relationele benadering zijn zij het veeleer zelf die mede de waarheid voortbrengen. Welnu, men kan niet producent en tegelijk product van de waarheid zijn. Het gaat hier werkelijk niet enkel om de logische, maar om de theologische prioriteit.

Ik denk aan wat Paulus zegt over de waarheid in ongerechtigheid ten onder houden, Romeinen $1: 18$. Hoe zal men dat nog kunnen zeggen, als een mens zegt: Ik worstel om de waarheid aan het licht te brengen. Zal de mogelijke verdonkering van de waarheid niet onderdeel van dat worstelingsproses kunnen zijn?

Paulus spreekt over het bewandelen van de rechte weg naar de waarheid van het Evangelie, Galaten $2: 14$. Hier komen we 
opnieuw voor de principiële prioriteit te staan. Moet de rechte weg aan de waarheid gemeten worden of is de waarheid product van en ontmoeting op het gaan van de rechte weg? Hier staan we voor een dilemma.

Dit rapport heeft een poging gedaan om op problemen in te gaan. Dat is te waarderen. De problemen van de gereformeerde kerken zijn die ook van andere kerken. Doch het principiële uitgangspunt voor de oplossing van de problemen ligt in een eigentydse visie op wat waarheid is en hoe waarheid tot stand komt. Slechts door deze visie over te nemen, kan de uitdaging van de moderne tijd beantwoord worden, zo meen ik de strekking van dit rapport te mogen samenvatten. Hier ligt mijn bezwaar. Niet dat men problemen signaleert. Wel dat men oplossingen zoekt, die in fundamento door het moderne denken en doen bepaald worden. Hier kan de Bijbel niet spreken zoals hij spreken wil en zoals hij gehoord moet worden.

Mijn conclusie is dan ook dat het waarheidsbegrip als sleutel voor het hele Schriftvraagstuk van filosofische aard is. Daartegen heeft een man als Calvijn juist zo gestreden. Hij heeft de heerschappij van de filosofie in de scholastiek gehekeld met een beroep op het spreken van de Schrift zelf.

De opzet van dit geschrift is er een van onderop. Het is geen wonder dat verscheidene scribenten karakteriseringen als coöperatie en synergisme hebben gebruikt ${ }^{11}$. Wie te werk gaat als hier gebeurt, moet tot een synergistische samenwerking van God en mens komen.

Het goddelijk karakter van de Schrift wordt wel beleden, maar niet gehonoreerd. Het valt ons moeilijk om dit te zeggen. We kunnen er echter niet onderuit. Het geloofsgetuigenis als kader voor de leer omtrent de Schrift betekent een afwijking van wat de gereformeerde theologie tot heden juist als kenmerkend voor de Schrift heeft beleden. God zorgt voor Zijn Woord, al schakelt Hij daarbij mensen in. Het is niet hún visie, hún geloof, hun theologischcultureel inzicht dat de boodschap bepaalt. Het is God Die Zich van hen bedient.

Hier wordt de gemeente onder het juk gebracht van een wijsgerig waarheidsbegrip. Dit waarheidsbegrip is tegelijk de invalspoort voor het onbeperkte, voluit gelegitimeerde gebruik van de historisch-kritische methode. Aan de resultaten daarvan wordt de gemeente overgeleverd. Het relationele waarheidsbegrip maakt het niet slechts mogelijk, doch zelfs noodzakelijk om die methode te gebruiken. Deze stelt ons immers in staat het proces van de waarheidswording te analyseren en te achterhalen.

Deze aanpak moet leiden tot een herschrijving van alle loci van de dogmatiek en tot een totaal nieuwe oriëntatie in de ethiek. Het is niet een kwestie van meer of minder, doch van principieel anders. Met dit rapport kan men noch wil men de ontwikkelingen in de gereformeerde kerken een halt toe roepen. Het is veeleer een legitimering van deze ontwikkelingen. Het rapport zelf is er een product van. Het kan dan ook niet kritisch tegenover die ontwikkelingen staan. 
Ik sluit af met twee stemmen over dit rapport.

Berkhof heeft zijn mening aldus samengevat. „De hoofdlijn wordt op den duur wel duidelijk: De bijbel is het verslag van mènsen die een ontmoeting met Gòd hebben en vertellen, hoe die bij hen aankomt - met de bedoeling dat ook wij er deel aan krijgen" ${ }^{12}$. Naar mijn oordeel heeft hij gelijk. Er zit ook teveel van Berkhofs dogmatiek in dit rapport verwerkt, dan dat Berkhof het niet zou begroeten als geheel in de lijn van het nieuwere, ook van zijn eigen denken.

Tenslotte: In Pretoria ontmoette ik prof. Joh. Heyns. Hij sprak er tegenover mij zijn verwondering over uit, dat Nederlandse kerken zo nadrukkelijk voor het relationele aspect van de waarheid pleiten en tegelijk met het blanke deel van Zuid Afrika de relaties niet meer nodig of mogelijk achten. Van relaties en relationaliteit gesproken.

Gelewer te Potchefstroom 25 Mei 1981.

\section{NO'TEN}

1 D. Nauta „Rapport over de aard van het schriftgezag”, in: Ouderlingen. blad, 58e jrg., nr 684, april 1981. Nauta vat zijn oordeel zo samen: „De synode heeft zich met andere woorden volledig achter het rapport gesteld $\mathrm{Zij}$ wil dat de inhoud ingedragen wordt onder de leden van alle gemeenten. Er wordt niet eens gevraagd, dat ter zake discussies zullen ontstaan of dat eventuele bezwaren kunnen worden ingebracht. Neen, allen moeten zonder meer met de inhoud vertrouwd gemaakt worden", biz. 6. Hij wijst dan verder op de taak van de kerkeraden om na te gaan „of er in hoeverre wij inderdaad van doen hebben met confessioneel verantwoorde uiteenzettingen. Met opzet gebruik ik hier het meervoud, het rapport vertoont bij nadere beschouwing betogen van uiteenlopende aard, met het ene kan men instemmen, met het andere verschillen", blz. 6. Ik wijs nu tegelijk op een aantal artikelen in onderscheiden kerkelijke organen die aan dit rapport zijn gewijd.

K. Runia schreef zes artikelen onder de titel „Over de aard van het Schriftgezag", in: Centraal Weekblad, 4 maart -3 april 1981, 29e jrg, 10-17. J. C de Moor ging in zes artikelen kritisch in op de beschouwingen van Runia. De Moor gebruikte steeds een andere titel voor zijn kritische reactie. Centraal Weekblad, 29 april -3 juni 1981, 29e jrg., nrs. 18-23.

Herman Ridderbos schreef drie artikelen in Gereformeerd Weekblad (Kok, Kampen) over ,de aard van het Schriftgezag", 20 maart-3 april 1981. H. de Jong schreef zes artikelen in Tot Opbonw „Over de aard van het Schriftgezag", 9 januari-13 februari 1981, 25e jrg., nrs $1-6$.

C. Graafland schreef 16 artikelen „De aard van het Schriftgezag”, De Waarheidsvriend, 5 Maart-2 juli 1981, 69e jrg., nrs. 10-27

W. van 't Spijker schreef zeven artikelen „De aard van het Schriftgezag". in De Wekker, 20 maart-8 mei 1981, 90e jgr., nrs 21-28.

Men zie ook Beweging, 45e jrg., no 3, juni 1981 met artikelen van $Z$. Schuurman, H. Geertsema, G. Groenewald en S. Griffioen.

2 C. A. van Peursen, $H i j$ is het weer. Beschouwingen over de betekenis van het woordje ,God', Kampen, z.j.s. 
Idem, Het is niet vanzelfsprekend, Kampen, z.j. Men kan in het oeuvre van Van Peursen nog verder teruggaan. Ik wijs op Cultuur en Christelijk geloof, Kampen 1955.

3 Ter vergelijking herinner ik aan discussies over de Christologie van Küng en Schillebeeckx. Beiden zeggen dat zij het dogma van de kerk ten volle aanvaarden, terwijl ze er toch een heel andere interpretatie van geven. Men zie hiervoor het boeiende artikel van Reinhard Slenczka, Christusbekenntnis und Christologie, in Kerygma und Dogma, 27e jrg., april/juni 1981, blz. 131-147 Men zie ook het derde artikel van W. van 't Spijker, 30 april 1981.

Men vergelijke wat $C$. J. den Heyer, een van de opstellers van het rapport, op 27 maart 1981, in zijn inaugurele oratie aan de VU zei, „Oude wijn is voortreffelijk". Over de noodzaak van onderwijs en onderzoek van het Jodendom aan een theologische faculteit, Kampen 1981, blz. 15: „Meer dan ooit blijkt de bijbel werkelijk een boek van mensen te zijn, met alle zwakheden van dien. Alleen op deze wijze is het Woord van God voor ons".

5 De uitdrukking bipolariteit vindt men op tal van plaatsen bij G. Heitink, Pastoraat als hulpverlening. Inleiding in de pastorale theologie en psychologie, Kampen 1977, vooral blz. 170-175. De beschouwingen van Berkhof in zijn Christelijk Geloof vormen in belangrijke mate de basis voor de conceptie van Heitink. Over Heitinks dissertatie zie men mijn bespreking in Theologie Reformata, 21 e jrg., nr 2, juni 1978, blz. 152-157.

Ook C. Graafland heeft gewezen op de overeenkomst en het rapport met de gedachten van $H$. Berkhof. Zie diens negende artikel, 14 mei 19981

6 Men vergelijke vooral Zonder geloof vaart niemand wel. Baarn 1974 2, blz. 107. I citeer wat uitvoerig om te wijzen op frapante overeenstemming tussen het door Kuitert gestelde en het in het rapport gevoerde betoog. „Openbaring betekent, dat God spreekt door mensen heen, die zeggen dat Hij spreekt, deze en deze dingen zegt, enz. Wij hebben Gods openbaring niet anders dan op de wijze van ons eigen spreken over God en zijn openbaring. Welnu, God spreekt door het spreken van de mensen heen, betekent dus eigenlijk: door het veranderende spreken van de mensen heen". Ik stel niet dat deze woorden precies zo in het rapport voorkomen. Ik stel wel, dat er tussen het in het rapport verdedigde relationele waarheids(en openbarings-)begrip én Kuiterts uitspraken een sterke, structurele overeenkomst bestaat.

7 Ik noem Arnold Gehlen, Anthropologisch Forschung. Zur Selbstbegegnung und Selbstentdeckung des Menschen. Hamburg 1961 (74-76 Tausend, 1976) en Wolfhart Pannenberg, Was ist der Mensch? Die Anthropologie der Gegenwart im Lichte der Theologie, Göttingen $1968^{3}$.

Idem, Der Mensch. Seine Natur und Stellung in der Welt, Wiesbaden, $1976 \%$.

8 Men bedenke dat op blz. 39 wordt gesteld dat het niet mogelijk is in dit rapport al een bespreking te geven van de principiële vragen rondom het historisch-kritisch onderzoek van de Bijbel. Ondanks de afwezigheid van deze bespreking worden de resultaten zonder kritisch verweer binnengehaald.

9 Zie vooral het derde artikel van Ridderbos. Het zwaartepunt van zijn kritiek treft men aan in deze zin: „Want de Bijbel biedt zich niet (in die eerste of voornaamste plaats) aan als een getuigenis van geloof, maar als een getuigenis van de openbaring; en dat met sterker nadruk, naarmate het gaat om de centrale heilsbetekenis die hij voor het geloof heeft... 
En ,getuigenis' betekent dan niet in de eerste plaats rekenschap afleggen van geloof, maar bericht van hetgeen eenmaal is geschied, gezegd en gedaan, door ooggetuigen is gezien en gehoord van al hetgeen Jezus gedaan heeft ,ten overstaan van', ,voor de ogen van zijn discipelen'

In deze kritiek herkent men de schrijver van Heilsgeschiedenis en Heilige Schrift. Het gezag van het Nieuwe Testament, Kampen 1955, met name de paragraaf over marturia, blz. 116-134.

10 Men zie vooral H. M. Kuitert, „Het schriftberoep in de Ethiek”, in: Anders gezegd. Theologische opstellen voor de welwillende lezer. Kampen 1970 , blz. 63-87, en het commentaar van J. Douma hierbij, in: Voorbeeld of gebod? Enkele opmerkingen over het Schriftberoep in de ethiek. Amsterdam, 1972 .

11 Voor Graafland zie met het zevende artikel (16 april 1981), voor Van 't Spijker diens zesde artikel (1 mei 1981).

12 H. Berkhof, De aard van het Schriftgezag, in: Kerkinformatie, $\mathrm{nr}$ 111, december 1980. In een discussie verklaarde een van de opstellers dat Berkhofs samenvatting de bedoeling van het rapport niet juist weergeeft. Het zou interessant zijn te vernemen welke argumenten vanuit de tekst van het rapport tegen de conclusie van Berkhof kunnen worden ingebracht. Op zichzelf is het niet ondenkbaar dat Berkhof zich vergist. Deze blijkt echter over het algemeen een goed inzicht te hebben in wat er zich afspeelt, èn in wat er verandert in theologie is. Hij weet dat over het algemeen ook goed te interpreteren. Daarom temeer is van betekenis dat we zouden horen op welke gronden de typering van Berkhof als onjuist van de hand wordt gewezen. 